\title{
Triplex real-time PCR assay for the authentication of camel-derived dairy and meat products
}

\author{
Xiao Hai, ${ }^{*}$ ㄴ) Guo-Qiang Liu, ${ }^{*}$ Jian-Xing Luo, ${ }^{*}$ Yuan-Sheng Guo, Jun-Ping Qian, Mei Ya, and Liang Guo† 다 \\ Xilingol Vocational College, Xilin Gol Institute of Bioengineering, Xilin Gol Food Testing and Risk Assessment Center, Xilinhot 026000, \\ Inner Mongolia, China
}

\begin{abstract}
Authentication of dairy and meat products is important to ensure fair competition, consumer benefit, and food safety. The large difference in price between camel and cow milk may be an incentive to adulterate camel dairy products with cow-derived foodstuffs. However, no studies so far have used triplex real-time PCR with an endogenous control to identify camel and cow origins in dairy and meat products. In this study, we developed a triplex real-time PCR assay based on amplification of mitochondrial $12 \mathrm{~S}$ ribosomal DNA for the authentication of camel-derived dairy and meat products. This method was applied to identify camel and cow DNA in milk, yogurt, cheese, milk powder, milk beverage, meat products, and mixtures with milk and meat. Concentrations as low as 1 to $5 \%$ and $0.1 \%$ camel milk and meat, respectively, were detected in the mixtures, and 1 to $5 \%$ and $0.1 \%$ cow milk and meat, respectively, were identified via this approach. The limits of detection were 0.005 to $0.0025 \mathrm{ng}, 0.05$ to 0.001 $\mathrm{ng}, 0.001$ to $0.0005 \mathrm{ng}$, and 0.00025 to $0.0001 \mathrm{ng}$ of DNA in camel milk, camel yogurt, commercial camel milk beverage, and camel meat, and from 0.0025 to $0.001 \mathrm{ng}, 0.5$ to $0.001 \mathrm{ng}, 1$ to $0.05 \mathrm{ng}, 0.01 \mathrm{ng}, 0.001$ $\mathrm{ng}, 0.0005$ to $0.00025 \mathrm{ng}, 0.0005$ to $0.00025 \mathrm{ng}$, and $0.005 \mathrm{ng}$ of DNA from cow milk, yogurt, cheese, acidic whey, milk powder, beef, beef jerky, and beef sausage, respectively. Different dairy and meat samples of camel and cow origins had a range of authentication limits and limits of detection. The designed triplex real-time PCR assay was shown to be a specific, sensitive, and efficient technique for the identification of camel and cow DNA in foodstuffs.
\end{abstract}

Key words: triplex real-time PCR, authentication, camel, dairy and meat products

Received July 11, 2019.

Accepted May 29, 2020.

*These authors contributed equally to this work.

†Corresponding author: herdman86@163.com

\section{INTRODUCTION}

Camels can survive and reproduce in harsh climatic conditions such as high temperature and drought, which is not suitable for other domestic mammals (Juliet, 1999; Abdel Gader and Alhaider, 2016). Camels play a significant role in the daily life of desert dwellers as a source of food and a means of transportation. Camels produce milk that is nutritionally similar to human milk (Zibaee et al., 2015). Studies have reported various health benefits of camel milk, including angiotensin-I-converting enzyme (ACE) inhibitory activity (Soleymanzadeh et al., 2019), hepatoprotective effect (Hamed et al., 2019), anti-inflammatory activity (Al-Omari et al., 2019), antioxidant effect (Wali et al., 2019), and antidiabetogenic effect (Aqib et al., 2019; Hammam, 2019). In addition, camel milk reduces the risk of heart disease (Aimutis, 2004), cancer (Rival et al., 2001), and autism (Mihic et al., 2016). These nutritional and therapeutic benefits make camel milk popular in the market. The economic profitability of the trade of camel milk encourages its production and sale. Nevertheless, the large difference in price between camel and cow milk may be an incentive to adulterate camel dairy products with cheaper cow dairy products (fresh milk, yogurt, cheese, milk powder, and milk beverage). Fraudulent adulteration of milk affects market growth by destroying consumer confidence and spending. Camels are important livestock in desert and semi-desert areas and are mainly used for producing milk and fleece and as draft animals. Camel meat is a by-product of traditional production in desert and semi-desert areas. Therefore, camel meat is not as popular as beef or mutton, and adulteration of camel meat is very rare. Nevertheless, the need for labeling authenticity and the risk of MERS (Middle East Respiratory Syndrome) mean that a method of identifying camel DNA in foods is urgently needed. In addition, although one study reported adulteration of camel meat in some countries in the Middle East (ElMorshedy et al., 2011), illegal substitution related to camel meat has not yet been reported in China. In this 
study, we developed a triplex real-time PCR for the simultaneous identification of camel and cow DNA.

Numerous methods have been developed for the authentication of dairy and meat products (Kumar et al., 2015; Rahmati et al., 2016; Clark and Mora Garcia, 2017). Among them, DNA-based techniques have high specificity and sensitivity due to the stability of DNA in the identification of closely related animal species in dairy and meat products (Hamzah et al., 2013; Lin et al., 2014; Ali et al., 2015). Adulteration of dairy and meat related to camel has been identified by conventional PCR assay (Deng et al., 2019; El-Morshedy et al., 2011) but few studies have reported on the development of multichannel real-time PCR method for identification of camel dairy and meat products.

The aim of this research was to develop a specific, efficient, and multichannel real-time PCR technique for the authentication of camel-derived dairy and meat products by identifying and distinguishing camel and cow DNA in milk, yogurt, cheese, milk powder, milk beverage, meat products, and mixtures of milk and meat. This 3-channel method was based on the design of species-conservative primers and species-specific probes targeting mitochondrial $12 \mathrm{~S}$ ribosomal DNA, which was validated by specificity, authentication, and sensitivity assays. Although camel and cow DNA could be identified individually using a PCR kit for each species, in this study, we developed the triplex real-time PCR for the simultaneous identification of camel and cow DNA. This technique is more efficient and economical than methods using 2 independent PCR reactions. More importantly, we designed an endogenous probe to be amplified with camel- and cow-specific probes to eliminate false-negative results, which hamper the legal impartiality of an authentication test. This triplex realtime PCR technique for simultaneous identification of camel and cow DNA could help resolve these practical problems and technical bottlenecks.

\section{MATERIALS AND METHODS}

\section{Collection of Dairy and Meat Products}

Camel and cow milks were collected from Mongolian yurts across Xilingol prairie in Inner Mongolia. Camel and cow yogurt (from spontaneous fermentation) were purchased from these Mongolian yurts. Cow milk powder, cow cheese, and camel milk beverage were purchased from Yili company (Hohhot, China), Ximulike dairy company (Xilinhot, China), and Wangyuan company (Sinkiang, China), respectively. Meat products of camel, beef, horse, sheep, goat, pork, buffalo, yak, chicken, duck, goose, dog, and rabbit were purchased from agricultural markets in Xilinhot, China. Camel dairy and meat products originated from Camelus bactrianus.

\section{Genomic DNA Extraction}

The genomic DNA from dairy products were extracted by the modified CTAB (cetyltrimethylammonium bromide) method (Guo et al., 2018). Camel and cow dairy products $(50 \mathrm{~mL}$ or $50 \mathrm{~g})$ were homogenized by PBS through low temperature and high-speed centrifugation $\left(4^{\circ} \mathrm{C}, 4,800 \times g, 10 \mathrm{~min}\right)$. The supernatant was discarded, the precipitate was washed with PBS (30 $\mathrm{mL})$ and centrifuged $\left(4^{\circ} \mathrm{C}, 4,800 \times g, 10 \mathrm{~min}\right)$. Then, PBS $(30 \mathrm{~mL})$ and emulsifier $(10 \mathrm{~mL})$ were added to the precipitate and incubated at $40^{\circ} \mathrm{C}$ for $10 \mathrm{~min}$. The precipitate was retained through centrifugation $\left(4^{\circ} \mathrm{C}, 4,800\right.$ $\times g, 10 \mathrm{~min})$ and washed twice more with PBS $(30 \mathrm{~mL})$ though centrifugation $\left(4^{\circ} \mathrm{C}, 4,800 \times g, 10 \mathrm{~min}\right)$. The precipitate was retained and the DNA extracted from it according to the standard CTAB method. TaKaRa MiniBEST Universal Genomic DNA Extraction Kit (Dalian, Liaoning, China) was used to isolate DNA from meat products according to the manufacturer's protocol. The DNA concentration and quality were assessed by NanoDrop2000c spectophotometer (Waltham, MA) at wavelengths of 260 and $280 \mathrm{~nm}$. The absorbance (A) ratio $\mathrm{A}_{260 \mathrm{~nm}}: \mathrm{A}_{280 \mathrm{~nm}}(1.7-1.9)$ indicated that the extracted DNA was suitable for real-time PCR.

\section{Triplex Real-Time PCR Primer and Probe Design and System Parameters}

To use the triplex real-time PCR for authentication, species-conservative primers simplify the PCR reaction and species-specific probes underpin the specificity of identification. Primers and probes were designed using Primer Premier 5.0 (Premier Biosoft International, Palo Alto, CA) in a species-specific manner to target highly conserved regions of the mitochondrial $12 \mathrm{~S}$ ribosomal DNA (Table 1). The primers and probes related to cow and endogenous control were as described in our previous research (Guo et al., 2018). Targeted sequences were screened by alignment of mitochondrial DNA from camel, cow, horse, sheep, goat, pig, buffalo, yak, chicken, duck, goose, dog, and rabbit. Camel, cow, and control probes were labeled with hexachlorofluorescein (HEX), 6-carboxyfluorescein (FAM), and carboxy-Xrhodamine (ROX), respectively. The camel sequences originated from both Camelus bactrianus and Camelus dromedarius, and camel-HEX can anneal template from both types of camel. The primers related to camel and cow determined the DNA fragment being amplified, and the 2 probes (camel-HEX and cow-FAM) competed with each other to bind the same amplified DNA 
Table 1. Triplex real-time PCR primers and probes

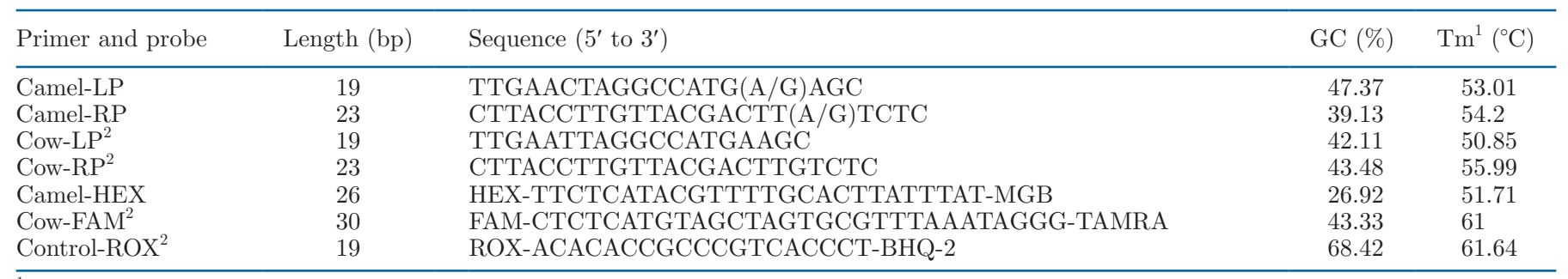

${ }^{1}$ Melting temperature.

${ }^{2}$ The sequence referred to our previous research (Guo et al., 2018). Camel, cow, and control probes were labeled with hexachlorofluorescein (HEX), 6-carboxyfluorescein (FAM), and carboxy-X-rhodamine (ROX), respectively.

fragments. The control probe can bind to the DNA fragments amplified both from camel and cow DNA, but the camel-specific or cow-specific probe can bind only to DNA fragments amplified from camel or cow DNA, respectively. The developed primers and probes were synthesized and purified by Ruibiotech Company (Beijing, China).

The triplex real-time PCR mixture consisted of 10 $\mu \mathrm{L}$ of probe quantitative PCR supermix (Transgen, Beijing, China); $0.5 \mu \mathrm{L}$ each of camel forward primer (camel-LP), cow forward primer (cow-LP), camel reverse primer (camel-RP), and cow reverse primer (cowRP) $(10 \mu M) ; 0.5 \mu \mathrm{L}$ each of camel-HEX $(10 \mu M)$, cow-FAM $(10 \mu M)$, and control-ROX $(10 \mu M) ; 2 \mu \mathrm{L}$ of DNA template $(100 \mathrm{ng} / \mu \mathrm{L})$; and $4.5 \mu \mathrm{L}$ of doubledistilled water (Transgen). The triplex real-time PCR was performed on ABI 7300plus (Applied Biosystems, Waltham, MA) using the following thermal profile: $94^{\circ} \mathrm{C}$ for $30 \mathrm{~s}$ (initial denaturation) and 40 cycles of $94^{\circ} \mathrm{C}$ for $5 \mathrm{~s}$ and $60^{\circ} \mathrm{C}$ for $31 \mathrm{~s}$ (quantification).

\section{Specificity, Authentication, and Sensitivity}

Specificity of the triplex real-time PCR assay was determined using DNA extracted from camel milk (fresh), camel yogurt, camel milk beverage, cow milk (fresh), cow yogurt, cow cheese, cow acidic whey, cow milk powder, camel meat (raw), beef (raw), beef jerky, beef sausage, and other dairy and meat products from nontarget species such as horse, mutton, pork, buffalo, yak, chicken, duck, goose, dog, and rabbit. The Ct results were confirmed using 3 independent dairy or meat samples related to camel or cow origin (3 replicates per run), and one dairy or meat sample from other origins was used to verify the specificity (3 replicates per run).

To simulate dairy and meat adulteration practices in the laboratory, 2 sets of milk mixtures (cow and camel milk mixtures; cow and camel yogurt mixtures), and 2 sets of meat mixtures (camel meat and chicken mixtures; beef and chicken mixtures) were used. The au- thentication assay was performed using these mixtures. Cow and camel milk were mixed in different ratios: 1 , $5,10,30,70,90,95$, and $99 \%$ (vol/vol) cow milk, and $99,95,90,70,30,10,5$, and $1 \%$ (vol/vol) corresponding camel milk, to prepare binary milk mixtures. Cow and camel yogurt were mixed in different ratios: $1,5,10$, 30, 70, 90, 95, and $99 \%$ (vol/vol) camel yogurt, and $99,95,90,70,30,10,5$, and $1 \%$ (vol/vol) corresponding cow yogurt, to prepare binary yogurt mixtures. We used chicken and camel meat or beef to stimulate the adulteration of fresh meat and to verify the authenticating ability of developed multichannel real-time PCR technique. Camel meat and chicken were mixed in different ratios: $0.1,1,10,30,70,90,99$, and $99.9 \%$ (wt/ wt) camel meat and 99.9, 99, 90, 70, 30, 10, 1, and $0.1 \%$ (wt/wt) corresponding chicken, to prepare binary meat mixtures. Beef and chicken were mixed in different ratios: $0.1,1,10,30,70,90,99$, and $99.9 \%$ (wt/wt) beef, and $99.9,99,90,70,30,10,1$, and $0.1 \%$ (wt/wt) corresponding chicken, to prepare binary meat mixtures. To mix meats from 2 origins homogeneously, we used liquid nitrogen to freeze the meats, and then ground and mixed them thoroughly in a crusher (Taisite, Tianjing, China) with liquid nitrogen for $4 \mathrm{~min}$. Three independent sets of dairy and meat mixtures were introduced to confirm the authentication limit of this technique. Twenty replicates per DNA sample from mixture were used, and the authentication results were analyzed by Probit analysis (Finney, 1971).

Sensitivity of the triplex real-time PCR assay was evaluated by determining the limit of detection (LOD). The LOD values were calculated using 10 -fold and 2-fold serial dilutions of DNA from dairy and meat products $(100,10,1,0.5,0.25,0.1,0.05,0.025,0.01$, $0.005,0.0025,0.001,0.0005,0.00025,0.0001,0.00005$, 0.000025 , and $0.00001 \mathrm{ng} / \mu \mathrm{L})$. Five independent DNA samples from dairy and meat samples were used to confirm the sensitivity. Twenty replicates per dilution were used, and the LOD was analyzed by Probit analysis (confidence limit: 95\%; Finney, 1971). 
A

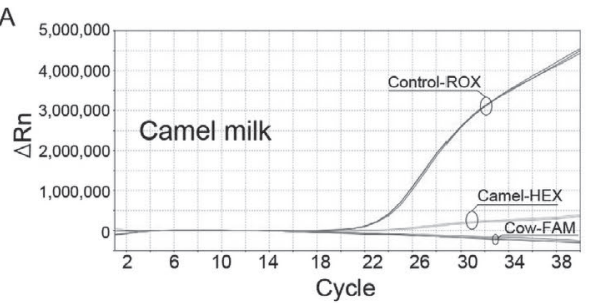

D

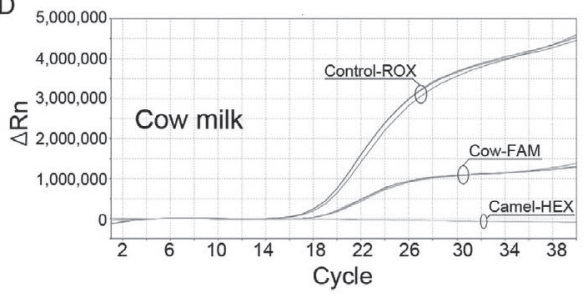

G

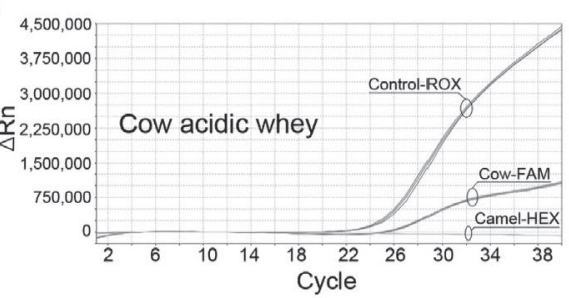

B

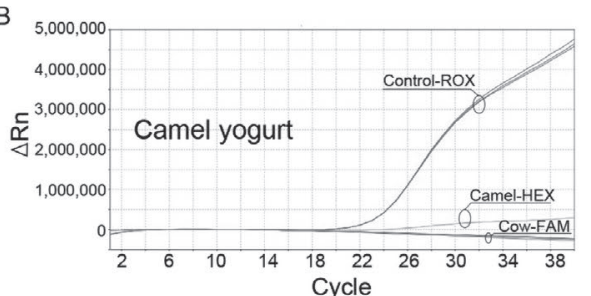

E

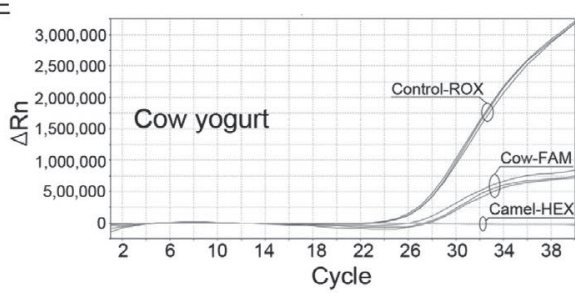

$\mathrm{H}$

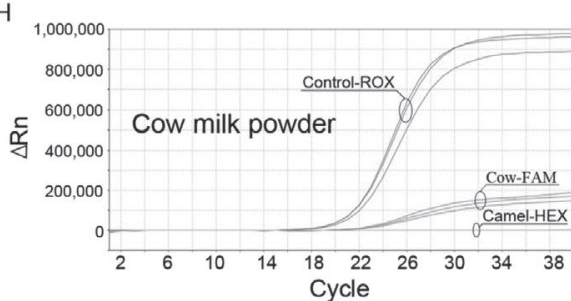

C

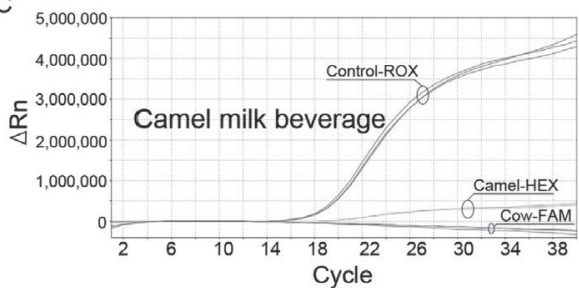

$\mathrm{F}$
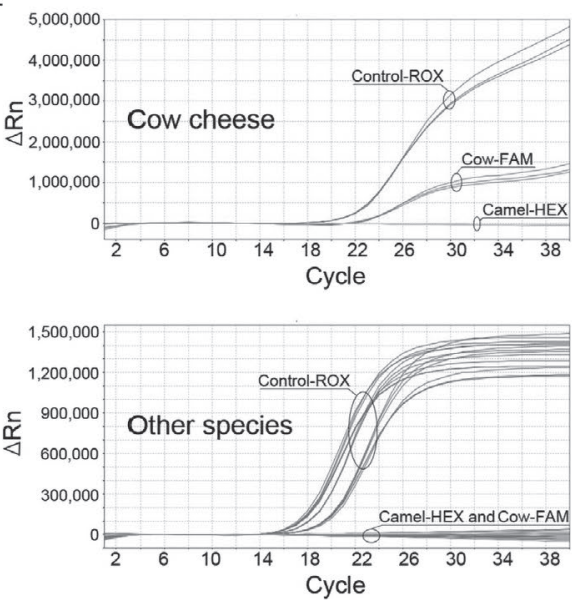

Figure 1. Amplification curves of the triplex real-time PCR assay showing specificity of the method in dairy products. Camel milk (A), camel yogurt (B), camel milk beverage (C), cow milk (D), cow yogurt (E), cow cheese (F), cow acidic whey (G), cow milk powder (H), and dairy products (mare milk, koumiss, goat milk, goat cheese, and goat milk powder) of other species (I). Experiments were performed in triplicate. $\Delta$ Rn $=$ normalized reported values minus baseline. Camel, cow, and control probes were labeled with hexachlorofluorescein (HEX), 6-carboxyfluorescein (FAM), and carboxy-X-rhodamine (ROX), respectively.

\section{RESULTS AND DISCUSSION}

\section{Specificity of the Triplex Real-Time PCR Assay}

Specificity of the triplex real-time PCR assay was determined using the designed probes to identify the corresponding DNA from camel or cow dairy and meat products. In the triplex real-time PCR reaction, amplification curves of camel-HEX were specifically observed for camel milk (Figure 1A), camel yogurt (Figure 1B), and camel milk beverage (Figure 1C), and amplification curves of cow-FAM were specifically observed for cow
A

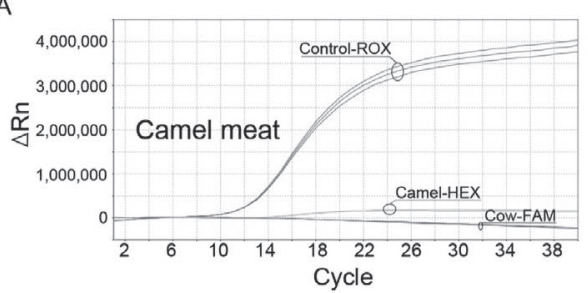

D

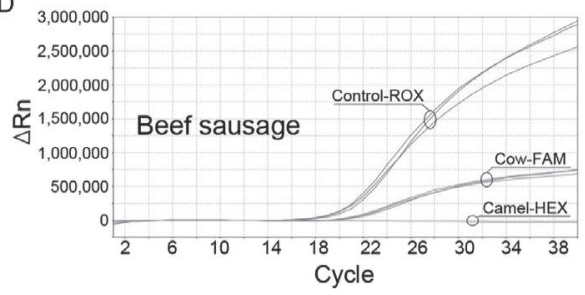

B

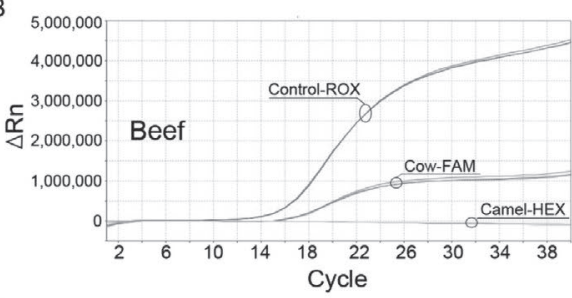

$\mathrm{E}$

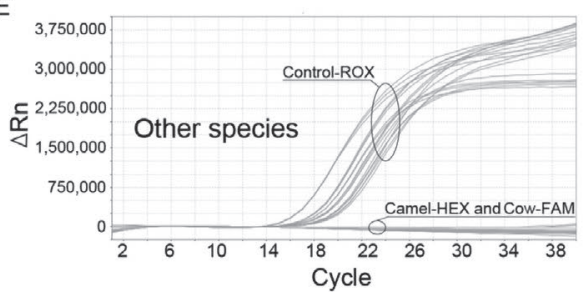

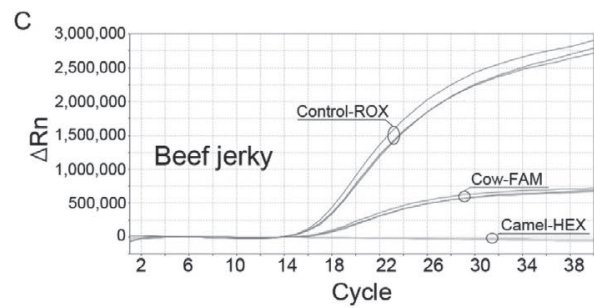

Pification curves of the triplex real-time PCR assay showing specificity of the method in meat products. Camel meat (A), beef (B), beef jerky (C), beef sausage (D), and meat products (horse, sheep, goat, pork, buffalo, and yak) of other species (E). Experiments were performed in triplicate. $\Delta \mathrm{Rn}=$ normalized reported values minus baseline. Camel, cow, and control probes were labeled with hexachlorofluorescein (HEX), 6-carboxyfluorescein (FAM), and carboxy-X-rhodamine (ROX), respectively. 
milk (Figure 1D), cow yogurt (Figure 1E), cow cheese (Figure 1F), cow acidic whey (Figure 1G), and cow milk powder (Figure 1H). The camel and cow probes did not target DNA from mare milk, koumiss, goat milk, goat cheese, and goat milk powder (Figure 1I). The number of dairy species (camel, cow, mare, and goat) limited the scope of this specificity assay, which required more species. Thus, various meat products from different species were used to confirm the specificity of camel and cow probes. In the assay to authenti- cate meat products, amplification curves of camel-HEX were specifically observed for camel meat (Figure 2A), and amplification curves of cow-FAM were specifically observed for beef (Figure 2B), beef jerky (Figure 2C), and beef sausage (Figure 2D). More importantly, camel-HEX and cow-FAM did not specifically anneal DNA from others species (Figure 2E). As shown in Table 2, the cycle threshold $(\mathbf{C t})$ values (mean $\pm \mathrm{SD}$ ) for all samples of the triplex real-time PCR assay were consistent with the amplification curves. The amplification

Table 2. The cycle threshold $(\mathrm{Ct})$ values of the triplex real-time PCR: specificity in dairy and meat products

\begin{tabular}{|c|c|c|c|}
\hline \multirow[b]{2}{*}{ Sample } & \multicolumn{3}{|c|}{ Ct value ${ }^{1}$} \\
\hline & Camel-HEX & Cow-FAM & Control-ROX \\
\hline \multirow[t]{3}{*}{ Camel milk $(\mathrm{n}=3)$} & $21.08 \pm 0.36$ & 0 & $14.20 \pm 0.19$ \\
\hline & $21.90 \pm 0.37$ & 0 & $14.55 \pm 0.30$ \\
\hline & $21.23 \pm 0.41$ & 0 & $14.94 \pm 0.61$ \\
\hline \multirow[t]{3}{*}{ Camel yogurt $(\mathrm{n}=3)$} & $18.46 \pm 0.79$ & 0 & $16.14 \pm 0.14$ \\
\hline & $20.17 \pm 1.28$ & 0 & $15.34 \pm 0.54$ \\
\hline & $13.84 \pm 0.33$ & 0 & $16.33 \pm 0.16$ \\
\hline \multirow{3}{*}{ Camel milk beverage $(\mathrm{n}=3)$} & $17.32 \pm 0.45$ & 0 & $14.10 \pm 0.19$ \\
\hline & $16.38 \pm 0.22$ & 0 & $13.88 \pm 0.03$ \\
\hline & $15.94 \pm 0.69$ & 0 & $13.89 \pm 0.04$ \\
\hline \multirow[t]{3}{*}{ Cow milk $(\mathrm{n}=3)$} & 0 & $15.34 \pm 0.23$ & $13.79 \pm 0.01$ \\
\hline & 0 & $15.42 \pm 0.24$ & $13.78 \pm 0.01$ \\
\hline & 0 & $14.92 \pm 0.06$ & $13.77 \pm 0.01$ \\
\hline \multirow[t]{3}{*}{ Cow yogurt $(\mathrm{n}=3)$} & 0 & $27.00 \pm 0.59$ & $22.74 \pm 0.24$ \\
\hline & 0 & $26.36 \pm 0.73$ & $22.60 \pm 0.11$ \\
\hline & 0 & $24.00 \pm 0.25$ & $18.82 \pm 0.11$ \\
\hline \multirow[t]{3}{*}{ Cow cheese $(\mathrm{n}=3)$} & 0 & $20.52 \pm 0.38$ & $14.24 \pm 0.12$ \\
\hline & 0 & $20.74 \pm 0.24$ & $13.96 \pm 0.01$ \\
\hline & 0 & $19.52 \pm 0.41$ & $13.96 \pm 0.06$ \\
\hline \multirow{3}{*}{ Cow acidic whey $(\mathrm{n}=3)$} & 0 & $25.59 \pm 0.14$ & $18.77 \pm 0.08$ \\
\hline & 0 & $25.09 \pm 0.08$ & $18.61 \pm 0.15$ \\
\hline & 0 & $21.40 \pm 0.44$ & $17.56 \pm 0.11$ \\
\hline \multirow[t]{3}{*}{ Cow milk powder $(\mathrm{n}=3)$} & 0 & $17.76 \pm 0.28$ & $14.00 \pm 0.10$ \\
\hline & 0 & $18.41 \pm 0.52$ & $13.97 \pm 0.06$ \\
\hline & 0 & $18.04 \pm 0.55$ & $14.24 \pm 0.13$ \\
\hline Mare milk & 0 & 0 & $13.77 \pm 0.01$ \\
\hline Koumiss & 0 & 0 & $13.76 \pm 0.01$ \\
\hline Goat milk & 0 & 0 & $13.79 \pm 0.02$ \\
\hline Goat cheese & 0 & 0 & $13.84 \pm 0.05$ \\
\hline Goat milk powder & 0 & 0 & $13.79 \pm 0.02$ \\
\hline \multirow[t]{3}{*}{ Camel meat $(\mathrm{n}=3)$} & $13.48 \pm 0.03$ & 0 & $13.29 \pm 0.01$ \\
\hline & $13.47 \pm 0.01$ & 0 & $13.29 \pm 0.01$ \\
\hline & $13.49 \pm 0.06$ & 0 & $13.31 \pm 0.05$ \\
\hline \multirow{3}{*}{ Beef $(\mathrm{n}=3)$} & 0 & $14.55 \pm 0.11$ & $13.75 \pm 0.01$ \\
\hline & 0 & $14.49 \pm 0.10$ & $13.75 \pm 0.05$ \\
\hline & 0 & $14.46 \pm 0.06$ & $13.74 \pm 0.01$ \\
\hline \multirow[t]{3}{*}{ Beef jerky $(\mathrm{n}=3)$} & 0 & $14.46 \pm 0.04$ & $13.74 \pm 0.01$ \\
\hline & 0 & $14.35 \pm 0.10$ & $13.74 \pm 0.01$ \\
\hline & 0 & $14.56 \pm 0.06$ & $13.83 \pm 0.02$ \\
\hline \multirow[t]{3}{*}{ Beef sausage $(\mathrm{n}=3)$} & 0 & $19.18 \pm 0.15$ & $15.93 \pm 0.23$ \\
\hline & 0 & $19.37 \pm 0.43$ & $15.95 \pm 0.23$ \\
\hline & 0 & $18.73 \pm 0.15$ & $15.59 \pm 0.14$ \\
\hline Horse meat & 0 & 0 & $16.50 \pm 0.05$ \\
\hline Sheep meat & 0 & 0 & $15.67 \pm 0.17$ \\
\hline Goat meat & 0 & 0 & $16.80 \pm 0.10$ \\
\hline Pork & 0 & 0 & $15.30 \pm 0.03$ \\
\hline Buffalo meat & 0 & 0 & $15.91 \pm 0.08$ \\
\hline Yak meat & 0 & 0 & $14.42 \pm 0.03$ \\
\hline
\end{tabular}


curves of control-ROX, the endogenous control, were synchronously and steadily amplified to validate the triplex real-time PCR in the state of amplification and to effectively control false-negative results.

To date, numerous studies have shown that PCR is the preferred technique for detection of food adulteration (Rahmati et al., 2016; Abbas et al., 2018). Conventional single-plex PCR for the identification of a single target is laborious, expensive, and logistically more complex than multiplex PCR (Ali et al., 2015; Xue et al., 2017). However, no studies have yet used triplex real-time PCR with an endogenous control to identify camel and cow origins in dairy and meat products. In this study, triplex real-time PCR synchronously and efficiently identified and distinguished camel and cow DNA in dairy and meat products.

\section{Authentication of Milk and Meat Adulteration in a Simulation System}

The specificity of the developed triplex real-time PCR allows counterfeit dairy and meat products to be detected. Fraudulent adulteration activities are often present in the market as a form of counterfeiting of foodstuffs. Therefore, we examined the ability of this developed technique to authenticate milk and meat products by simulating different types of adulteration. In the first binary milk mixtures containing cow and camel milk, camel-HEX detected 5\% camel milk (Table 3; confidence limit: 95\%) and cow-FAM detected $1 \%$ cow milk (Table 3; confidence limit: 95\%). In the second and third binary milk mixtures containing cow and camel milk, camel-HEX detected 1\% camel milk (Table 3; confidence limit: 95\%) and cow-FAM detected 5\% cow milk (Table 3; confidence limit: 95\%). In binary yogurt mixtures containing camel and cow yogurt, camel-HEX detected 1 to $5 \%$ camel yogurt (Table 4; confidence limit: $95 \%$ ) and cow-FAM detected 1 to $5 \%$ cow yogurt (Table 4; confidence limit: 95\%). As shown in Tables 3 and 4 , the authentication limits of camel and cow were inconsistent in the 3 binary dairy mixtures, and camelHEX or cow-FAM achieved $1 \%$. We speculated that camel and cow somatic cell number or mass per unit volume varied in different samples. Different relative somatic cell number or mass resulted in inconsistency of the authentication limits. In the binary meat mixtures containing camel meat and chicken, camel-HEX detected $0.1 \%$ camel meat (Table 5 ; confidence limit: $95 \%$ ). In the binary meat mixtures containing beef and chicken, cow-FAM detected $0.1 \%$ cow meat (Table 5 ; confidence limit: 95\%). In contrast to dairy samples, meat products have relatively stable cell numbers or mass per unit mass in muscle tissue from camel meat and beef. The relatively stable quantity of DNA from camel meat and beef resulted in consistency of authentication limits.

The Ct values (mean $\pm \mathrm{SD}$ ) of the triplex real-time PCR assay increased with decreasing corresponding dairy and meat components in the mixtures (data not shown). Control-ROX was amplified with all mixtures. These experiments showed the sensitivity and specificity of triplex real-time PCR assay in identifying very low contents of the target species in milk and meat mixtures, and the sensitivity was measurably higher in the current study than in the previous studies (Brodmann and Moor, 2003; Cheng et al., 2014).

\section{Sensitivity of the Triplex Real-Time PCR Assay}

The LOD of the developed triplex real-time PCR assay was examined using 10 -fold and 2-fold serial dilutions of DNA from dairy products such as camel milk, camel yogurt, camel milk beverage, cow milk, cow yogurt, cow cheese, cow acidic whey, and cow milk

Table 3. The cycle threshold $(\mathrm{Ct})$ values (mean $\pm \mathrm{SD}$ ) of the triplex real-time PCR: authentication of camel and cow milk

\begin{tabular}{|c|c|c|c|c|}
\hline \multicolumn{2}{|c|}{ Volume (\%) } & \multicolumn{3}{|c|}{ Ct value ${ }^{1}$} \\
\hline Camel milk & Cow milk & Camel-HEX & Cow-FAM & Control-ROX \\
\hline 99 & 1 & $18.58 \pm 1.37$ & $37.13 \pm 4.66$ & $16.59 \pm 0.24$ \\
\hline 1 & 99 & 0 & $24.30 \pm 0.66$ & $16.97 \pm 0.39$ \\
\hline 5 & 95 & $28.46 \pm 2.52$ & $19.53 \pm 0.65$ & $14.28 \pm 0.16$ \\
\hline 99 & 1 & $14.96 \pm 0.54$ & 0 & $14.13 \pm 0.13$ \\
\hline 95 & 5 & $25.68 \pm 1.01$ & $30.84 \pm 0.62$ & $20.20 \pm 0.54$ \\
\hline 1 & 99 & $28.07 \pm 1.17$ & $24.19 \pm 0.33$ & $17.08 \pm 0.39$ \\
\hline 99 & 1 & $12.71 \pm 0.58$ & 0 & $14.20 \pm 0.12$ \\
\hline 95 & 5 & $26.59 \pm 0.72$ & $30.61 \pm 0.62$ & $19.94 \pm 0.56$ \\
\hline 1 & 99 & $28.74 \pm 1.41$ & $21.95 \pm 0.41$ & $15.00 \pm 0.43$ \\
\hline
\end{tabular}

${ }^{1}$ The result was estimated by Probit analysis using 20 replicates for each mixture. Camel, cow, and control probes were labeled with hexachlorofluorescein (HEX), 6-carboxyfluorescein (FAM), and carboxy-X-rhodamine (ROX), respectively. 
Table 4. Cycle threshold $(\mathrm{Ct})$ values $($ mean $\pm \mathrm{SD})$ of the triplex real-time PCR: authentication of camel and cow yogurt

\begin{tabular}{|c|c|c|c|c|}
\hline \multicolumn{2}{|c|}{ Volume (\%) } & \multicolumn{3}{|c|}{ Ct value ${ }^{1}$} \\
\hline Camel yogurt & Cow yogurt & Camel-HEX & Cow-FAM & Control-ROX \\
\hline 99 & 1 & $18.61 \pm 0.47$ & $30.41 \pm 2.45$ & $14.03 \pm 0.19$ \\
\hline 1 & 99 & 0 & $20.40 \pm 0.40$ & $15.91 \pm 0.43$ \\
\hline 5 & 95 & $35.39 \pm 1.99$ & $22.31 \pm 0.36$ & $21.43 \pm 0.23$ \\
\hline 99 & 1 & $12.88 \pm 0.26$ & 0 & $15.50 \pm 0.66$ \\
\hline 95 & 5 & $25.13 \pm 0.82$ & $30.93 \pm 1.07$ & $18.44 \pm 0.75$ \\
\hline 1 & 99 & $27.9 \pm 0.31$ & $26.47 \pm 0.32$ & $19.12 \pm 0.49$ \\
\hline 99 & 1 & $12.90 \pm 0.07$ & 0 & $15.97 \pm 0.21$ \\
\hline 95 & 5 & $23.58 \pm 0.58$ & $29.11 \pm 0.73$ & $16.41 \pm 0.56$ \\
\hline 1 & 99 & $23.26 \pm 1.04$ & $20.5 \pm 0.44$ & $14.2 \pm 0.24$ \\
\hline
\end{tabular}

${ }^{1}$ The result was estimated by Probit analysis using 20 replicates for each mixture. Camel, cow, and control probes were labeled with hexachlorofluorescein (HEX), 6-carboxyfluorescein (FAM), and carboxy-X-rhodamine (ROX), respectively.

powder, and meat products such as camel meat, beef, beef jerky, and beef sausage. The LOD of camel DNA detection in camel milk, camel yogurt, camel milk beverage, and camel meat were 0.005 to $0.0025 \mathrm{ng}$ (Figure $3 \mathrm{~A}), 0.05$ to $0.001 \mathrm{ng}$ (Figure 3B), 0.001 to $0.0005 \mathrm{ng}$ (Figure 3C), and 0.00025 to $0.0001 \mathrm{ng}$ (Figure 3D), respectively (confidence limit: $95 \%$; Table 6 ). The LOD of cow DNA detection in cow milk, cow yogurt, cow cheese, cow acidic whey and cow milk powder, beef, beef jerky, and beef sausage were 0.0025 to $0.001 \mathrm{ng}$ (Figure 3E), 0.5 to $0.001 \mathrm{ng}$ (Figure 3F), 1 to $0.05 \mathrm{ng}$ (Figure 3G), $0.01 \mathrm{ng}$ (Figure 3H), $0.001 \mathrm{ng}$ (Figure 3I), 0.0005 to $0.00025 \mathrm{ng}$ (Figure 3J), 0.0005 to 0.00025 ng (Figure 3K), and 0.005 ng (Figure 3L), respectively (confidence limit: 95\%; Table 6).

This study demonstrated that the real-time PCR assay based on the developed primers and probes was sensitive for authentication of camel and cow dairy and meat products. The LOD for these foodstuffs was lower than previous studies (Chisholm et al., 2005; Zhang et al., 2007; Agrimonti et al., 2015; Di Domenico et al., 2017), which indicates the sensitivity of the developed assay. In addition, sensitivity was lower for processed milk or meat products compared with fresh milk and raw meat (Table 6). Fermentation and heat treatment may disrupt the integrity of the DNA, which may have reduced the sensitivity of the assay. In addition, different dairy and meat samples from camel and cow origins showed a range of LOD. The quality and integrity of DNA from samples may determine the consistency of LOD in the triplex real-time PCR. Processing and storage of dairy and meat products could affect extraction of DNA by affecting somatic cell numbers or mass per unit volume or mass of sample.

To determine the linearity of the triplex real-time PCR assay, DNA from dairy and meat products was serially diluted (10-fold) and used as templates. Calibration curves were constructed by plotting the resulting $\mathrm{Ct}$ values against the logarithm of DNA concentrations. The slope of the calibration curve, efficiency, and coefficient of determination $\left(\mathrm{R}^{2}\right)$ for the dairy and meat products are shown in Table 7 . The above results indicated a significant linear relationship between the Ct values and the logarithm of the DNA concentrations

Table 5. The cycle threshold $(\mathrm{Ct})$ values $($ mean $\pm \mathrm{SD})$ of the triplex real-time PCR: authentication of camel meat and beef

\begin{tabular}{|c|c|c|c|c|c|}
\hline \multicolumn{3}{|c|}{ Mass (\%) } & \multicolumn{3}{|c|}{ Ct value ${ }^{1}$} \\
\hline Camel meat & Beef & Chicken & Camel-HEX & Cow-FAM & Control-ROX \\
\hline 0.1 & 0 & 99.9 & $24.09 \pm 0.47$ & 0 & $16.09 \pm 0.52$ \\
\hline 0 & 0.1 & 99.9 & 0 & $22.60 \pm 0.39$ & $18.15 \pm 2.14$ \\
\hline 0.1 & 0 & 99.9 & $23.57 \pm 0.71$ & 0 & $15.55 \pm 0.46$ \\
\hline 0 & 0.1 & 99.9 & 0 & $24.68 \pm 0.20$ & $18.13 \pm 0.55$ \\
\hline 0.1 & 0 & 99.9 & $22.75 \pm 0.85$ & 0 & $14.85 \pm 0.49$ \\
\hline 0 & 0.1 & 99.9 & 0 & $24.66 \pm 0.36$ & $18.31 \pm 0.74$ \\
\hline
\end{tabular}

${ }^{1}$ The result was estimated by Probit analysis using 20 replicates for each mixture. Camel, cow, and control probes were labeled with hexachlorofluorescein (HEX), 6-carboxyfluorescein (FAM), and carboxy-X-rhodamine (ROX), respectively. 
A

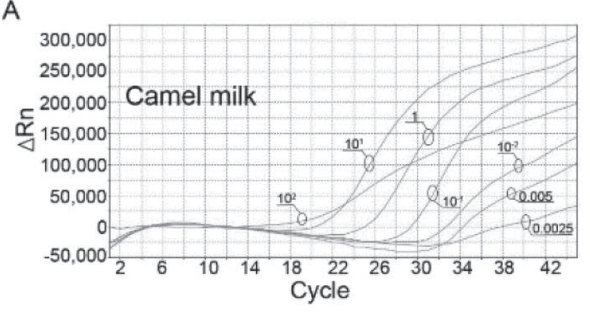

D

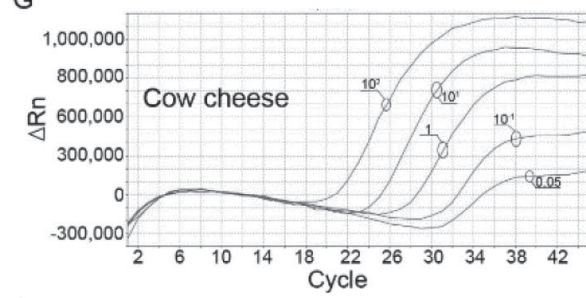

$\checkmark$

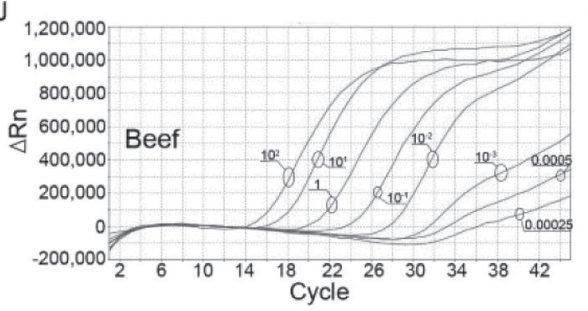

B

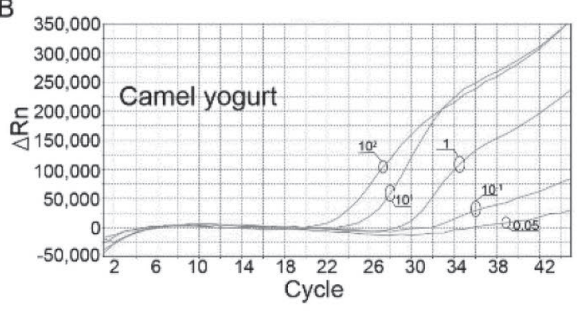

E
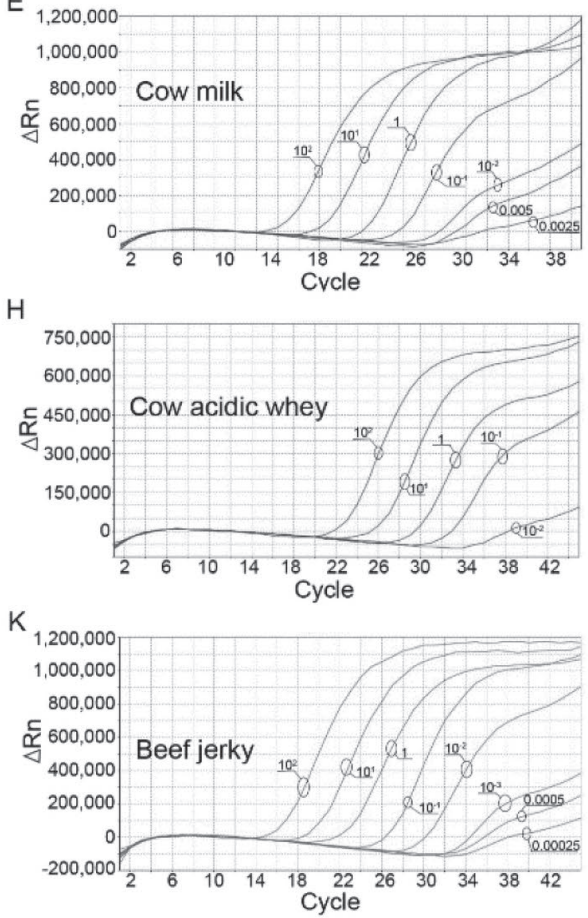

c

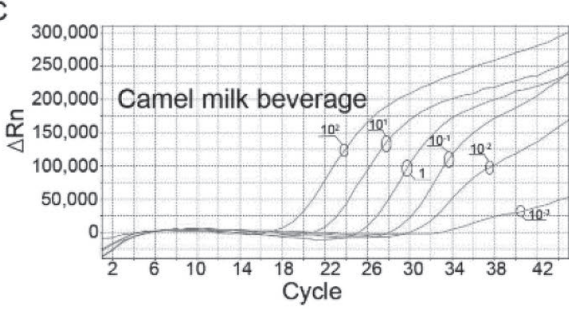

F

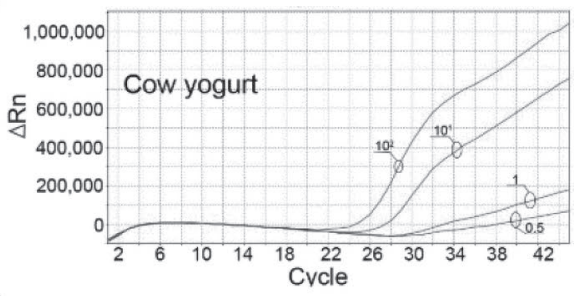

I

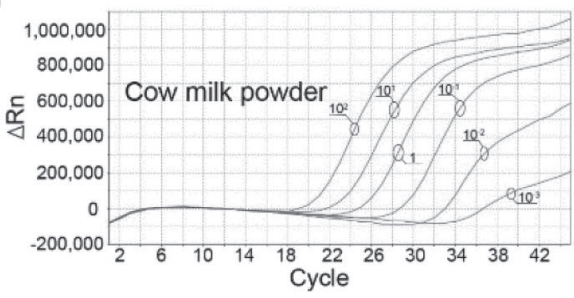

L

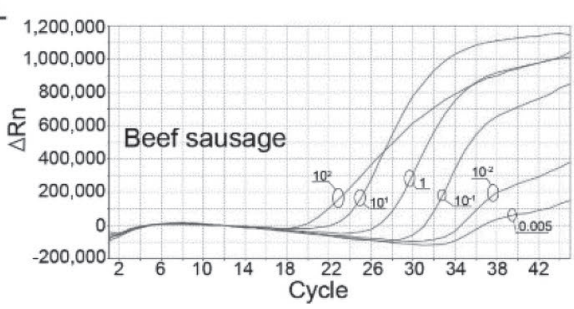

Figure 3. Amplification curves of the triplex real-time PCR assay showing sensitivity in dairy and meat products (demonstrating one biological sample in 5). Camel milk (A), camel yogurt (B), camel milk beverage (C), camel meat (D), cow milk (E), cow yogurt (F), cow cheese (G), cow acidic whey $(\mathrm{H})$, cow milk powder $(\mathrm{I})$, beef $(\mathrm{J})$, beef jerky $(\mathrm{K})$, and beef sausage $(\mathrm{L})$ were identified by the triplex real-time PCR assay. The results were confirmed using 20 replicates. $\Delta \mathrm{Rn}=$ normalized reported values minus baseline.

Table 6. Cycle threshold (Ct) values of the triplex real-time PCR: sensitivity assay in dairy and meat products (5 biological replicates)

\begin{tabular}{lc}
\hline Sample & Limit of detection $(\mathrm{ng})^{1}$ \\
\hline Camel milk & $0.005-0.0025$ \\
Camel yogurt & $0.05-0.001$ \\
Camel milk beverage & $0.001-0.0005$ \\
Camel meat & $0.00025-0.0001$ \\
Cow milk & $0.0025-0.001$ \\
Cow yogurt & $0.5-0.001$ \\
Cow cheese & $1-0.05$ \\
Cow acidic whey & 0.01 \\
Cow milk powder & 0.001 \\
Beef & $0.0005-0.00025$ \\
Beef jerky & $0.0005-0.00025$ \\
Beef sausage & 0.005 \\
\hline
\end{tabular}

${ }^{1}$ The limit of detection was estimated by Probit analysis using 20 replicates for each dilution.
Table 7. The slope of the calibration curve, efficiency, and the coefficient of determination $\left(\mathrm{R}^{2}\right)$ for the dairy and meat products

\begin{tabular}{lccc}
\hline Sample & Slope & Efficiency $(\%)$ & $\mathrm{R}^{2}$ \\
\hline Camel milk & -4.794 & 61.66 & 0.9934 \\
Camel yogurt & -4.721 & 62.86 & 0.9991 \\
Camel milk beverage & -4.354 & 69.70 & 0.9989 \\
Camel meat & -4.115 & 74.99 & 0.9992 \\
Cow milk & -4.126 & 74.73 & 0.9997 \\
Cow yogurt & -4.784 & 61.82 & 0.9991 \\
Cow cheese & -4.123 & 74.80 & 0.9999 \\
Cow acidic whey & -4.015 & 77.45 & 0.9984 \\
Cow milk powder & -3.806 & 83.12 & 0.9972 \\
Beef & -3.992 & 78.03 & 0.9969 \\
Beef jerky & -4.054 & 76.47 & 0.9972 \\
Beef sausage & -4.084 & 75.73 & 0.9999 \\
\hline
\end{tabular}


$\left(\mathrm{R}^{2}>0.99\right)$. The efficiency of the developed method was very low. We speculate that control-ROX and camel-HEX or cow-FAM were simultaneously amplified in the triplex real-time PCR, and competition for PCR resources imposed restrictions on the efficiency of the developed method. This method was not suitable for quantification. We assumed that triplex real-time PCR of a mitochondrial gene (multicopy) would be more suitable for qualitative than quantitative detection, whereas an amplified gene from nuclear DNA is suitable for quantitative.

\section{CONCLUSIONS}

In this study, a triplex real-time PCR assay was developed to authenticate camel-derived dairy and meat products. This method was based on using highly conserved regions of the mitochondrial $12 \mathrm{~S}$ ribosomal DNA to design species-conservative primers and species-specific probes. In this study, we highlighted the specificity, authentication, and sensitivity of the assay, which were adequate to detect and authenticate camel dairy and meat products. Different dairy and meat samples from camel and cow origins had a range of authentication limits and LOD. The quality, integrity, and relative quantity of DNA from samples may affect the consistency of data in the triplex real-time PCR. Currently, the increased incidence of milk and meat fraud raises concerns about food safety and marketing standards. Establishment of specific, sensitive, and efficient approaches for species identification will help authenticate animal-derived dairy and meat products and identify fake and substandard food products.

\section{ACKNOWLEDGMENTS}

This work was supported by Inner Mongolia Natural Science Foundation (2020MS03065), Inner Mongolia College Science Research Project (NJZY20312 and NJZY19337), and Inner Mongolia Talent Development Fund. The authors declare that they have no conflicts of interest.

\section{REFERENCES}

Abbas, O., M. Zadravec, V. Baeten, T. Mikus, T. Lesic, A. Vulic, J. Prpic, L. Jemersic, and J. Pleadin. 2018. Analytical methods used for the authentication of food of animal origin. Food Chem. 246:6-17. https://doi.org/10.1016/j.foodchem.2017.11.007.

Abdel Gader, A. G. M., and A. A. Alhaider. 2016. The unique medicinal properties of camel products: A review of the scientific evidence. J. Taibah Univ Med Sci. 11:98-103. https://doi.org/10 .1016/j.jtumed.2015.12.007.

Agrimonti, C., A. Pirondini, M. Marmiroli, and N. Marmiroli. 2015. A quadruplex PCR (qxPCR) assay for adulteration in dairy products. Food Chem. 187:58-64. https://doi.org/10.1016/j.foodchem 2015.04.017.
Aimutis, W. R. 2004. Bioactive properties of milk proteins with particular focus on anticariogenesis. J. Nutr. 134:989S-995S. https:// doi.org/10.1093/jn/134.4.989S.

Al-Omari, M. M., R. B. Al-Ghariebeh, A. A. A. Alhaija, H. Al-Zoubi, and K. M. Al-Qaoud. 2019. Camel milk whey inhibits inflammatory colorectal cancer development via down-regulation of pro-inflammatory cytokines in induced AOM/DSS mouse model. Emir. J. Food Agric. 31:256-262. https://doi.org/10.9755/ejfa.2019.v31 .i4.1935.

Ali, M. E., M. A. Razzak, S. B. A. Hamid, M. M. Rahman, M. A. Amin, N. R. Rashid, and Asing.. 2015. Multiplex PCR assay for the detection of five meat species forbidden in Islamic foods. Food Chem. 177:214-224. https://doi.org/10.1016/j.foodchem.2014.12 .098 .

Aqib, A. I., M. F.-A. Kulyar, K. Ashfaq, Z. A. Bhutta, M. Shoaib, and R. Ahmed. 2019. Camel milk insuline: Pathophysiological and molecular repository. Trends Food Sci. Technol. 88:497-504. https: //doi.org/10.1016/j.tifs.2019.04.009.

Brodmann, P. D., and D. Moor. 2003. Sensitive and semi-quantitative TaqMan real-time polymerase chain reaction systems for the detection of beef (Bos taurus) and the detection of the family mammalia in food and feed. Meat Sci. 65:599-607. https://doi.org/10 .1016/S0309-1740(02)00253-X.

Cheng, X., W. He, F. Huang, M. Huang, and G. Zhou. 2014. Multiplex real-time PCR for the identification and quantification of DNA from duck, pig and chicken in Chinese blood curds. Food Res. Int. 60:30-37. https://doi.org/10.1016/j.foodres.2014.01.047.

Chisholm, J., C. Conyers, C. Booth, W. Lawley, and H. Hird. 2005. The detection of horse and donkey using real-time PCR. Meat Sci. 70:727-732. https://doi.org/10.1016/j.meatsci.2005.03.009.

Clark, S., and M. B. Mora Garcia. 2017. A 100-year review: Advances in goat milk research. J. Dairy Sci. 100:10026-10044. https://doi .org/10.3168/jds.2017-13287.

Deng, L., A. Li, Y. Gao, T. Shen, H. Yue, J. Miao, R. Li, and J. Yang. 2019. Detection of the bovine milk adulterated in camel, horse, and goat milk using duplex PCR. Food Anal. Methods 13:560-567. https://doi.org/10.1007/s12161-019-01678-2.

Di Domenico, M., M. Di Giuseppe, J. D. Wicochea Rodriguez, and C. Camma. 2017. Validation of a fast real-time PCR method to detect fraud and mislabeling in milk and dairy products. J. Dairy Sci. 100:106-112. https://doi.org/10.3168/jds.2016-11695.

El-Morshedy, A., E. Eldaly, A. El-Atabany, and A. Tharwat. 2011. Identification of adulteration with camel meat using polymerase chain reaction assay. J. Am. Sci. 7:339-343.

Finney, D. J. 1971. Probit Analysis. 3rd ed. Cambridge University Press, Cambridge, UK.

Guo, L., J. P. Qian, Y. S. Guo, X. Hai, G. Q. Liu, J. X. Luo, and M. Ya. 2018. Simultaneous identification of bovine and equine DNA in milks and dairy products inferred from triplex TaqMan real-time PCR technique. J. Dairy Sci. 101:6776-6786. https://doi.org/10 .3168/jds.2018-14408.

Hamed, H., K. Bellassoued, A. El Feki, and A. Gargouri. 2019. Evaluation of the hepatoprotective effect of combination between fermented camel milk and Rosmarinus officinalis leaves extract against $\mathrm{CCl} 4$ induced liver toxicity in mice. J. Food Sci. Technol. 56:824-834. https://doi.org/10.1007/s13197-018-3542-y.

Hammam, A. R. 2019. Compositional and therapeutic properties of camel milk: A review. Emir. J. Food Agric. 31:148-152. https:// doi.org/10.9755/ejfa.2019.v31.i3.1919.

Hamzah, A., S. A. Mutalib, and A. S. Babji. 1571. 2013. Comparison between Mt-DNA D-Loop and Cyt B primers for porcine DNA detection in meat products. Am. Inst. Phys. Conf. Ser. 669-673. https://doi.org/10.1063/1.4858731.

Juliet, C.-B. 1999. Camels and llamas. Pages 151-159 in A Natural History of Domesticated Mammals. 2nd ed. University of Cambridge, Cambridge, UK.

Kumar, A., R. R. Kumar, B. D. Sharma, P. Gokulakrishnan, S. K. Mendiratta, and D. Sharma. 2015. Identification of species origin of meat and meat products on the DNA basis: A review. Crit. Rev. Food Sci. Nutr. 55:1340-1351. https://doi.org/10.1080/10408398 .2012 .693978 . 
Lin, C. C., L. L. Fung, P. K. Chan, C. M. Lee, K. F. Chow, and S. H. Cheng. 2014. A rapid low-cost high-density DNA-based multidetection test for routine inspection of meat species. Meat Sci. 96:922-929. https://doi.org/10.1016/j.meatsci.2013.09.001.

Mihic, T., D. Rainkie, K. J. Wilby, and S. A. Pawluk. 2016. The therapeutic effects of camel milk: A systematic review of animal and human trials. J. Evid. Based Complementary Altern. Med. 21:NP110-26. https://doi.org/10.1177/2156587216658846.

Rahmati, S., N. M. Julkapli, W. A. Yehye, and W. J. Basirun. 2016. Identification of meat origin in food products-A review. Food Control 68:379-390. https://doi.org/10.1016/j.foodcont.2016.04.013.

Rival, S. G., S. Fornaroli, C. G. Boeriu, and H. J. Wichers. 2001. Caseins and casein hydrolysates. 1. Lipoxygenase inhibitory properties. J. Agric. Food Chem. 49:287-294. https://doi.org/10.1021/ jf000392t.

Soleymanzadeh, N., S. Mirdamadi, M. Mirzaei, and M. Kianirad. 2019. Novel $\beta$-casein derived antioxidant and ACE-inhibitory active peptide from camel milk fermented by Leuconostoc lactis PTCC1899: Identification and molecular docking. Int. Dairy J. 97:201-208. https://doi.org/10.1016/j.idairyj.2019.05.012

Wali, A., G. Yanhua, U. Ishimov, A. Yili, H. A. Aisa, and S. Salikhov. 2019. Isolation and identification of three novel antioxidant pep- tides from the Bactrian camel milk hydrolysates. Int. J. Pept. Res. Ther. 26:641-650. https://doi.org/10.1007/s10989-019-09871-x.

Xue, C., P. Wang, J. Zhao, A. Xu, and F. Guan. 2017. Development and validation of a universal primer pair for the simultaneous detection of eight animal species. Food Chem. 221:790-796. https:// doi.org/10.1016/j.foodchem.2016.11.102.

Zhang, C. L., M. R. Fowler, N. W. Scott, G. Lawson, and A. Slater. 2007. A TaqMan real-time PCR system for the identification and quantification of bovine DNA in meats, milks and cheeses. Food Control 18:1149-1158. https://doi.org/10.1016/j.foodcont.2006.07 .018.

Zibaee, S., S. M. Hosseini, M. Yousefi, A. Taghipour, M. A. Kiani, and M. R. Noras. 2015. Nutritional and therapeutic characteristics of camel milk in children: A systematic review. Electron. Physician 7:1523-1528. https://doi.org/10.19082/1523.

\section{ORCIDS}

Xiao Hai $\odot$ https://orcid.org/0000-0001-9144-7446

Liang Guo @ 1 https://orcid.org/0000-0002-1954-1179 